\title{
International Law and International Institutions: Implications for a Rising China
}

\author{
Qingjiang Kong \\ Professor of Law at China University of Political Science and Law, \\ Beijing, China \\ qkong20oo@hotmail.com \\ Xiaojuan Ping \\ Research Assistant at the East Asian Institute, National University of Singapore, \\ Singapore
}

\begin{abstract}
There is a growing concern that China has become more assertive in its foreign policies. The fear is whether China's economic growth may translate into modern and effective military advancement. This engenders the critical question of whether China feels comfortable in the current international order, which is defined by international law and institutions. This article argues that the Chinese approach to international law and institutions is tightly associated with its evolving attitudes towards them. With its opening-up, China now views multilateralism as a way for the international community to constrain the capriciousness of a superpower, and regards the international institutions simply as power sharing development. However, China's integration in international institutions represents its attempt to work within international norms to pursue its interests. It also shows China's effort to hedge against American influence, and signals China's emergence as an active player in the international arena.
\end{abstract}

\section{Keywords}

International law - International institutions - International dispute settlement - Rise of China

* I would like to thank Professor Zheng Yongnian for his insightful comments, and gratefully acknowledge the editorial assistance of Ms. Jessica Loon.

(C) KONG AND PING, 2016 DOI 10.1163/23525207-12340009

This is an open access article distributed under the terms of the Creative Commons Attribution- 
Speculation is rife that China will overtake the United States as the world's largest economy by 2020 after having surpassed the latter in 2014 based on parity terms of purchasing power. ${ }^{1}$ The prospect has aroused concerns from the current power centres about the possible confrontations and challenges it may bring. Many observers even refer to the USSR or Wilhelmine Germany as a parallel to contemporary China, when viewed as a potential challenger to the United States. $^{2}$

China is perceived to have adopted a visibly aggressive foreign policy. For example, China has forged links with anti-American governments in Venezuela, Iran and Russia. Since Xi Jinping's assumption of office in 2012, China's neighborhood policies have noticeably been more assertive regarding territorial disputes in the East and South China Seas.

Some China observers are concerned about the translation of China's economic growth, not only into modern and effective military advancement, but also a resurgent Chinese foreign policy. The most pressing matter about China's rise involves security concerns in the East Asia region.

Some believe that the rise of China's economy will eventually ignite conflict. China might seek either a realignment of power in the region or secure its control of the disputed islands in the East and South China Seas as its influence grows by force. ${ }^{3}$

Some analysts identify China's goal in the near term as preventing these islands from falling within the territorial scope of its neighbouring disputant countries. They also fear that in the long term China will seek to project power

1 The International Comparison Programme (ICP), coordinated by the World Bank, released comparison GDP estimates for 2011 in April 2014. See "China Set to Overtake U.s. as Biggest Economy Using P PP Measure”, Bloomberg News, 29 April 2014.

2 Joshua Cooper Ramo, "The gap between how China sees itself and others see it is wide and dangerous", Newsweek, 25 September 2006 issue. A recent article is even more concerned about the impact of China as a rising power, see John J. Mearsheimer, "Can China Rise Peacefully?", The National Interests, September-October Issue.

3 See John J. Mearsheimer, Can China Rise Peacefully? 8 April 2014, at http://nationalinterest.org/commentary/can-china-rise-peacefully-10204, accessed on 28 September 2015. See also Eric A. Posner and John Yoo, "International Law and The Rise of China", Public Law \& Legal Theory Working Papers, No. 127, 2006. This paper can be downloaded without charge at the Public Law and Legal Theory Working Paper Series: http://www.law.uchicago.edu/ academics/publiclaw/index.html and The Social Science Research Network Electronic Paper Collection: http://ssrn.com/abstract_id=901997. 
beyond its territory and territorial waters. ${ }^{4}$ China observers argue that China's military buildup has begun to alter the balance of power in East Asia.

This engenders the critical question of whether China will feel comfortable in the current international order defined by international law and institutions. China's attitude towards international law and institutions is evolving in tandem with its perception of international law in the discourse of sovereignty and globalisation. Indeed, China has practiced the peaceful settlement of international disputes through either negotiation or judicial resolution. China's relations with the rest of the world are not as simple as many have perceived.

\section{International Order: The Evolving Chinese Attitude and Approach}

The general sentiment towards multilateral institutions has not been positive in recent years. The antipathy largely emanates from the misgivings about these institutions' catchy quantitative and qualitative expansion. International organisations have expanded their regulatory domains to areas which are traditionally the prerogatives of domestic constituencies of their member states.

International institutions have also been transformed into entities going beyond their typical roles. This gives rise to the concern that as massive power continues to concentrate in the hands of unelected bureaucrats, international institutions become more distant from the general public and are less accountable.

Interestingly, unlike the concerned general public, both the Chinese government and its citizens regard this issue simply as a matter of power sharing. In fact, the legitimacy of international institutions has never been singled out for meticulous and systemic study in China.

References to this issue in Chinese literature are rare; they do not even appear in a law student's curriculum. It is only touched upon in the discourse on international order which has been heatedly debated among students of international relations. ${ }^{5}$ An appreciation of the Chinese approach to international norms

4 Eric A. Posner and John Yoo, "International Law and The Rise of China", Public Law and Legal Theory Working Papers, No. 127, 2006.

5 Serious related research works include Ye Jiang and Tan Tan, "On the Legitimacy of International Institutions and its Defects" (in Chinese), World Economics and Politics, No. 12, 2006; and Wang Lefu and Li Weiquan, "A Study of the Issue of Legitimacy of Subjects in International Governance in the Context of Globalization" (in Chinese), Journal of Sun Yat-sen University, No. 9, 2003. 
would thus necessitate a thorough understanding of China's attitude towards the international order.

In Mao's era, China rejected the rules of the international system and referred to "revolution (nao gemin)" in seeking social changes. Mao's foreign policy legacy was noted for its bombastic language, strong opposition to the superpowers, especially the United States and the Soviet Union, close association with developing countries, and relative isolation from international organisations and economic autarky.

Deng Xiaoping's reform and opening-up policy in the late 1970s kick-started China's engagement with the international community. Consequently, China expanded its international profile by significantly increasing its participation in intergovernmental and nongovernmental organisations, especially financial institutions such as the World Bank (шв) and the International Monetary Fund (IMF).

The transformation deepened in the early 1990s when Beijing expanded its multilateral links to facilitate economic growth. China then began to establish various levels of "partnership" to enhance its economic and security cooperation with the outside world, culminating in the signing of the Treaty of GoodNeighbourliness and Friendly Cooperation between China and Russia in 2001.

Since the late 1990s, China has begun to engage with the Association of Southeast Asian Nations (ASEAN), holding annual meetings with senior officials from ASEAN countries as of 1995. China assisted with the initiation of the "ASEAN + 3" mechanism, a series of yearly meetings of the 10 ASEAN countries plus three Northeast states including China, Japan and South Korea.

Next came the Framework Agreement on Comprehensive Economic Cooperation between ASEAN and China, which was based on the "ASEAN +1 " mechanism. With the Framework Agreement signed, a China-ASEAN free trade area emerged within the following 10 years.

More importantly, an updated version of the China-ASEAN free trade agreement is being discussed. ${ }^{6} \mathrm{~A}$ declaration on a code of conduct was signed in 2002, primarily for the purpose of settling territorial disputes between China and some ASEAN member states. Interestingly, the final document included most of the draft language sought by ASEAN — and little of what was offered by China.

China also deepened its participation in the Asia-Pacific Economic Cooperation (APEC) Forum, hosting the ninth leaders' meeting in Shanghai

6 Discussions to upgrade China-ASEAN FTA negotiations was on the agenda of the Fifth Meeting of the Joint Commission of the China-Asean Free Trade Area (FTA) held in Chengdu, Sichuan from 11 to 13 March 2014. 
in 2001. While abiding by its claims to the islands based on historical evidence, China has now repeatedly committed itself to settling the territorial disputes peacefully, based on international law.

In Northeast Asia, the China-Japan-South Korea Free Trade Agreement (FTA) has been under negotiation since 2012 and an FTA between China and Korea was concluded in 2015. The trilateral relationship dipped to a low point when Prime Minister Shinzo Abe visited the Yasukuni Shrine in December 2013. Moves to beef up military forces by both Japan and China have only increased suspicion and friction over disputed islands after Japan nationalized the Diaoyu/Senkaku Islands in September 2012.

Since Abe's Yasukuni Shrine visit, in particular, China has been quite vocal about refusing to hold meetings with Japanese officials. Xi Jinping and Abe did not hold any meetings until the APEC Summit in November 2014. However, the continuing negotiation of the free trade agreement seems to indicate that China, Japan, and South Korea are willing to put aside their political differences for shared economic benefits. ${ }^{7}$

In Central Asia, China led the establishment of the region's first multilateral organisation, the Shanghai Cooperation Organisation (sco). Founded to settle long-standing territorial disputes and to demilitarise borders, the sco expanded its mission to counterterrorism cooperation and regional trade following the " $9 / 11$ " terrorist attack on the United States. The Xi administration has proposed a Silk Road Economic Belt and a Maritime Silk Road of the 21th Century to resume historical connections and consolidate the economic links between countries along the Silk Road. ${ }^{8}$

China has spared no effort in improving its ties with Europe since the end of the Cold War. In 1996, China was a founding member of the Asia-Europe Meeting, which holds bi-annual summit meetings for heads of state and yearly ministerial meetings. China and the EU have also initiated an annual political dialogue. More noteworthy is that China made public a document entitled "White Paper on China's EU Policy", which enunciated its relations with the EU as "crucial". China and the EU established a "strategic partnership" to institutionalize bilateral relations in 2004.

With the United States China has established a Strategic and Economic Dialogue, amid the ups and downs of U.s./China relations, as a forum for consultation over disputes between the two countries. China has also engaged the

7 Shannon Tiezzi, "China-Japan-South Korea Hold fta Talks Despite Political Tension", The Diplomat, 5 March 2014.

8 Kong Qingjiang, "Develop Together for Common Prosperity" (in Chinese), People's Daily, 3 July 2014. 
United States in facilitating a bilateral investment agreement. The agreement under negotiation is based on a high-standard investment regime for foreign investment, characterised by post-establishment national treatment for foreign investors and international arbitration for investor-state disputes. ${ }^{9}$

First of all, the evolving process represents China's deeper participation in the international system and its attempt to rebuild its international image to protect and promote its economic interests and to enhance national security. Secondly it demonstrates China's attempt to hedge against American influence around the world. More importantly, it signals a larger transformation: China's emergence as an active player in the international arena.

Although the changes are precipitated by the motivation to protect its own interests, China now accepts many prevailing international norms and institutions. Beijing is thus prepared to work within international norms to pursue its interests.

\section{The Chinese Perception of International Law in the Discourse of Sovereignty and Globalisation}

Sovereignty can be historically understood through two broad movements. The first was the development of a system of sovereign states, culminating in the Peace of Westphalia in 1648. The second was the circumscription of the sovereign state, which began in practice after World War II and has continued since through European integration and the strengthening of laws to protect human rights. As a result, it becomes increasingly unclear if there is legitimate power above and beyond that of sovereign states.

China seems to adhere to the traditional understanding of sovereignty. ${ }^{10}$ Its approach has its basis in Chinese tradition. The teachings of Confucius, which served the Chinese Empire well for more than 2,000 years, acknowledged the "natural order of things" and gave great weight, in particular, to the supremacy of the family above all other institutions. ${ }^{11}$ Manifested in its social institutions,

$9 \quad$ Kong Qingjiang, "Us-China Bilateral Investment Treaty Negotiations: Context, Focus, and Implications", Asian Journal of WTO and International Health Law and Policy, Volume 7, No. 1, 2012.

10 For a detailed discussion of the People's Republic of China's perception of sovereignty, see Cheng Hu, Globalisation and State Sovereignty (in Chinese), Beijing, Tsinghua University Press, 2003, pp. 112-122.

11 A typical example is that during some dynastical periods sons could not be prosecuted for aiding and abetting a criminal father because it was natural that a family would aid and shelter its own members. 
Chinese tradition tends to grant legitimacy to a hierarchy of priorities, which still has a bearing on modern Chinese perception. ${ }^{12}$

China has in place a well developed policy agenda for economic reform. It has constructed a discourse on international norms that reinforces and justifies its opening-up policy. Thus, China can retain its sovereignty and capacities, despite the challenges and risks that international norms represent.

Although caution and conservatism are still visible in China's attitude towards international norms, the Chinese ambition to enjoy the privileges of a great power in international institutions is evident. The argument that as China's power accumulates it will be just a matter of time before it rigorously promotes international norms with Chinese characteristics is thus plausible. ${ }^{13}$

However, China has been frustrated by contemporary international norms that are undoubtedly influenced by a U.s. supremacy that is often tantamount to unilateralism and which does not guarantee the effective functioning of international norms; such supremacy may sometimes even constitute a threat to the legitimacy or democratic decision-making process of international institutions.

Sovereignty, globalisation and international norms are intertwined. In this context, multilateralism is set up to be beneficial as it promotes the legitimacy of transnational governance. It provides a platform for members of the international community to express their ideas and negotiate with one another.

From the Chinese point of view, multilateralism is a way for the international community to constrain the capriciousness of a superpower and for international institutions to avoid/address misunderstandings. This is particularly important when more developing countries and relatively weaker powers seek to pursue global governance through international institutions.

After all, transnational democracy — albeit at its early stages—should thus not be forgotten where democracy is a keyword in domestic policy. Faced with an array of international institutions that do not fit China's preferred type, China has generally shown a preference for cooperation over conflict in dealing with these institutions. China is expected to continue cooperating with other states within the boundaries of international rules and norms of behaviour.

The two criteria for judging the existence of a democratic mechanism or a balance of interests of the institution's constituent members in the institution's decision-making process are, first, whether the big powers among the

\footnotetext{
12 For an argument that Confucianism still serves as the mode of governance in contemporary China, see Ross Terrill, The New Chinese Empire: And What It Means for the United States, New York, Basic Books, 2003.

13 See, for example, Marc Lanteigne, China and International Institutions: Alternative Paths to Global Powers, London and New York, Routledge, 2005, Chapter 5.
} 
institution's members share power or responsibility facilitated by the presence of a, formal or informal, consultative mechanism between them; and, second, whether the interests of developing countries at large are taken into consideration in the decision-making process. Disputes

In theories of international law, there are two peaceful approaches to dispute settlement: the political approach and the juridical approach. The former includes consultation and negotiation, ${ }^{14}$ good offices, conciliation, investigation and mediation. All the means are applicable to all types of international disputes..$^{15}$ In the latter, disputes are resolved by an institution that has independent jurisdiction. Both litigation and international arbitration belong to this category.

The Chinese government upholds the peaceful settlement of international disputes as a fundamental principle of international law. In principle, the settlement of international disputes should be in accordance with the principles of the Charter of the United Nations and should not contravene the fundamental principles of international relations.

Moreover, making use of good offices, arbitration or mediation committees under the auspices of the United Nations should facilitate labour distribution and coordination among the General Assembly, the Security Council and the Secretary General; it should be instrumental in the checks and balances of their obligations under the Charter of the United Nations concerning the maintenance of international peace and security as well. ${ }^{16}$

Article 2 of the Charter of the United Nations recognises the peaceful settlement of international disputes as a principle and outlaws non-peaceful

14 Strictly speaking, consultation is a form of negotiation. Professor J.G. Merrills examined consultation as a means to dispute settlement in the first chapter-The Negotiation-of his book International Dispute Settlement, Cambridge, Cambridge University Press, 1998, pp. $1-8$.

15 Cao Jian-ming, Zhou Hong-jun and Wang Hu-hua (ed.), Public International Law, Law Press, 1998, pp. 627-629.

16 Liu Li-yang's speech on the peaceful settlement of international disputes at the Sixth Committee of the United Nations General Assembly, Chinese Yearbook of International Law, 1998, Law Press, 1999, p. 700. 
solutions to international disputes. ${ }^{17}$ China holds that the peaceful settlement of various international disputes should be in accordance with the principles embodied in the Charter of the United Nations and other principles concerning international relations.

When seeking political solutions to international disputes, respect has to be given to the sovereignty and territorial integrity of all states involved; resort to the threat of or the use of force or refusing to accept the outcome to a dispute are to be avoided. ${ }^{18}$

China also upholds the stand that disputes between sovereign states should be resolved through dialogue, a 'proper approach' to the peaceful solution to international disputes. ${ }^{19}$ The dialogue approach that China advocates is equivalent to consultation and negotiation, an important approach to the political settlement of international disputes.

China supports a strong United Nations role in the prevention of conflicts. It further holds that political solutions to international disputes cannot be replaced by the United Nations' peacekeeping activities. China strongly opposes the excessive use of force in peacekeeping activities, and emphasises that principles such as respect for national sovereignty and non-interference in another state's internal affairs should be observed in peacekeeping activities. ${ }^{20}$

For example, to strengthen the Secretary General's role in conflict prevention, the rules of the Charter of the United Nations regarding the interrelations among agencies concerned should also be observed so as to maintain balance and coordination. ${ }^{21}$

The peaceful settlement of international disputes is allowed to appear in the form of both a political solution and a judicial solution in international law. The persistent position of China, however, only implies the former, which encompasses mediation, arbitration, conciliation and negotiation.

17 Li Huan-ting's speech on the peaceful settlement of international disputes at the 4oth Meeting of the Sixth Committee of the United Nations General Assembly, Chinese Yearbook of International Law, 1986, Law Press, 1987, p. 610.

18 Huan-ting Li's speech on the peaceful settlement of international disputes at the 4oth Meeting of the Sixth Committee of the United Nations General Assembly, Chinese Yearbook of International Law, 1986, Law Press, 1987, see p. 610.

19 Wang Hou-li's speech on the Report of the Special Political Committee of the Charter of the United Nations at the 41st Meeting of the Sixth Committee of the United Nations General Assembly, Chinese Yearbook of International Law, 1987, Law Press, 1988, p. 827.

$20 \quad$ Liu En-zhao, The United Nations Peacekeeping Activities, Law Press, 1999, pp. 252-254.

21 Wang Hou-li's speech on the Report of the Special Political Committee of the Charter of the United Nations at the 41st Meeting in the Sixth Committee of the United Nations General Assembly, Chinese Yearbook Of International Law, 1987, Law Press, 1988, p. 827. 
China thus has its own interpretation of what constitutes the peaceful settlement of international disputes. To date, China has always, as a third party or as one of the permanent members of the Security Council of the UN, required or urged the disputing parties to resolve their disputes by juridical means.

\section{The Chinese Practice of the Settlement of International Disputes}

\subsection{Negotiation and Consultation}

China attaches great importance to negotiation and consultation as international dispute settlement schemes. In China's foreign relations, a lot of issues of vital importance to China and those rooted in history were settled by direct negotiation and consultation between the Chinese government and the other parties involved.

Territorial and boundary disputes between China and its neighbouring countries have given rise to most of the controversies in recent years. China has had such controversies with India, Pakistan, Myanmar and Russia. ${ }^{22}$ It has a territorial dispute over the Diaoyu/Senkaku Islands with Japan and over the Nansha/Spratly Islands with Vietnam, the Philippines, Malaysia and Brunei.

The Chinese practice shows that China has unexceptionally solved or attempted to solve all of these territorial and boundary disputes by way of negotiation and consultation. It is also opposed to resolving the dispute of the Nansha/Spratly Islands via arbitration, an approach which is to be hosted by a third party. ${ }^{23}$

With the negotiation and consultation approach, the Chinese government has settled its boundary disputes with Russia, Pakistan and Myanmar. In 196o, as a result of diplomatic negotiations between the Chinese government and the government of the Union of Myanmar, an agreement was signed on border issues, which led to the resolution of the boundary dispute between China and Myanmar. $^{24}$

Subsequently, the boundary disputes between China and Pakistan and Nepal were respectively settled by means of negotiation or consultation; China and Russia (previously the Soviet Union) reached an agreement, by means of negotiation, on the eastern part of the Sino-Soviet border in 1991, an agreement

\footnotetext{
22 Liu Hai-shan, International Law, Beijing, Law Press, 1992, pp. 201-212.

23 Fang Lian-qin, Liu Jin-zhi and Wang Bing-yuan, Post-War History of International Relations, Beijing, Peking University Press, 1996, pp. 1059-1065.

24 Wang Tie-ya, International Law, Law Press, 1995, p. 610.
} 
on the western part of the Sino-Russian border in 1994 and a supplementary agreement on the eastern part of their shared border in 2005.

Almost concurrently, China signed border demarcation agreements respectively with Kazakhstan, Kirghizstan and Tajikistan on the basis of negotiation and consultation. ${ }^{25}$ Again by way of negotiation, China signed a land boundary treaty with Vietnam in 1999 and an agreement on the demarcation of the Gulf of Tonkin territorial sea in 2000.

Other international disputes that are of great political or economic importance were also resolved through negotiation. For example, several issues on the non-proliferation of nuclear weapons were settled through negotiation and consultation. ${ }^{26}$

Negotiation was also the mechanism responsible for settling disputes on intellectual property, trade in textiles, and other matters with the United States; the two major trade partners managed to reach peaceful understandings between themselves. ${ }^{27}$

China has not resorted to resolving international disputes through good offices. However, conciliation was once employed by China as a means to resolve disputes in the case of a border skirmish that had broken out between India and China in 1962. Six African and Asian countries had put forward a proposal with a view to mediating the conflict. The Chinese government accepted the proposal as the basis for the commencement of direct negotiations between India and China. ${ }^{28}$

With regard to the settlement of disputes relating to the territorial integrity and national sovereignty of China or its other vital interests, apparently, China has opposed any conciliation or mediation by a third party.

For instance, China refused U.s. intervention in the Taiwan issue and the dispute concerning the Nansha/Spratly Islands. ${ }^{29}$ So far, China has no record

25 Li Shou-yuan, International Relations and the Diplomacy of China, Beijing, Beijing Broadcasting Institute Press, 1999, p. 173.

26 Li Shou-yuan, International Relations and the Diplomacy of China, Beijing, Beijing Broadcasting Institute Press, 1999, p. 282.

27 Fang Lian-qin, Liu Jin-zhi, Wang Bing-yuan, Post-War History of International Relations, Beijing, Peking University Press, 1996, pp. 948-958.

28 India's requirement that China accept the proposal unconditionally led to the breakdown in the mediation effort.

29 China also turned down the offer of Lee Kuan Yew, Senior Minister of Singapore, to conciliate the dispute by taking advantage of his good relations with both sides of the Taiwan Strait. 
of having resolved a dispute, to which China itself is a party, by means of investigation and mediation. ${ }^{30}$

However, China has contributed to the settlement of international disputes as a mediator. In order to find a peaceful solution to the Cambodian issue, for example, China took an active part in the large-scale United Nations-led collective mediation, which resulted in a solution to the 13-year old dispute. ${ }^{31}$

China is keen to resolve international disputes by diplomatic means-negotiation and consultation-, but not the two juridical means-international arbitration and judicial resolution. China is reluctant to take part in proceedings before an international court or in international arbitration, reflecting its distrust of international courts and tribunals, or at least its sense of estrangement therefrom. Western international lawyers blame this on China's historical sense of humiliation. ${ }^{32}$

In all the treaties - except some foreign trade protocols - that China signed before the 1980s, there were no arbitration clauses. China made reservations, if permitted, to almost all the arbitration clauses in the multilateral treaties and international conventions that it signed, acceded to or ratified.

In the late 1980s, China had a change of mind when it made no reservation to the arbitration provisions of international conventions it signed, acceded to or ratified. These conventions usually dealt with economic development, trade, technology, transportation, aviation, the environment, health care or other areas of professional or technical cooperation. ${ }^{33}$

3o Wang Tie-ya, International Law, Law Press, 1995, p. 611.

31 Liu Ming, International Intervention and National Sovereignty, Chengdu, Sichuan People's Publishing House, 2000, pp. 191-192.

32 For example, J.A. Cohen and H. Chiu, People's China and International Law, Princeton, 1974 and Shao-chun Leng (ed.), Law in Chinese Foreign Policy: Communist China and Selected Problems of International Law, Dobbs Ferry, 1972.

33 In 1988, China acceded to the Convention Establishing the Multilateral Investment Guarantee Agency, which requires that disputes between contracting parties and the organisations be settled by means of negotiation, mediation or arbitration. When it ratified the Convention on the Settlement of Investment Disputes between States and Nationals of Other States in 1992, China agreed to submit to the International Centre for Settlement of Investment Disputes (ICSID) disputes concerning expropriation and compensation. When it ratified the United Nations Convention to Combat Desertification in Those Countries Experiencing Serious Drought and/or Desertification, Particularly in Africa in 1996, and when it acceded to or ratified the Convention of the International Telecommunication Union and the International Telecommunication Convention in 1997, China did not make reservations to the arbitration clauses. 
While acceding to some political conventions, China still made reservations to their arbitration clauses. ${ }^{34}$ Meanwhile, arbitration clauses and dispute settlement clauses in general (including arbitration) were seen in treaties and agreements in bilateral trade, investment, technology cooperation and cultural exchange.

For example, in accordance with Article 6 of the Agreement between the United States of America and the People's Republic of China on Investment Insurance and its accompanying Exchange of Notes, if a dispute cannot be resolved through negotiation, the government of either party may submit an arbitration application.

Similar provisions are incorporated in the bilateral investment agreements China signed with France, the United Kingdom, the Netherlands and Canada. However, in the bilateral treaties on extradition or on judicial assistance that China signed, there were no provisions concerning dispute settlement by arbitration, there were only clauses referring to diplomatic methods or negotiation and consultation. ${ }^{35}$

Based on the principle that all sovereign states are equal and independent, the Chinese government insists that, without the consent of a country, any other country or international organisation has no power to exercise jurisdiction over national sovereignty. Thus, in 1972, soon after the resumption of its seat at the Un, the People's Republic of China announced that the statement, which the former Republic of China had made to accept the compulsory jurisdiction of the International Court of Justice (ICJ), was ineffective.

China has not signed agreements with other countries that mandate the submission of disputes to the ICJ. This is also the case regarding international conventions it has acceded to or ratified; even if such clauses do exist in those conventions, China will make a reservation to those clauses.

As the ICJ's role in the peaceful settlement of disputes has been gradually strengthened, China's attitude towards settling international disputes before the ICJ has also changed. China has become more open to such provisions

34 Reservations were made to the arbitration provisions of the Convention on the Prevention and Punishment of Crimes Against Internationally Protected Persons Including Diplomatic Persons in 1987 and to judicial settlement and arbitration (Article 66) of the Vienna Convention on the Law of Treaties in 1997.

35 The Extradition Treaty between the People's Republic of China and the Kingdom of Thailand (Article 19), The Treaty on the Civil and Commercial Legal Assistance between the People's Republic of China and the Kingdom of Spain (Article 28), The People's Republic of China and Canada treaty on judicial assistance in criminal cases (Article 32), and other Judicial Assistance Treaties signed between China and Greece, the Republic of Korea, Singapore and the United States have similar provisions. 
when it accedes to or ratifies international conventions. ${ }^{36}$ However, no dispute or case has been referred to the ICJ by China so far. ${ }^{37}$

Part 15 of the United Nations Convention on the Law of the Sea (China ratified the Convention in May 1996) has an optional compulsory jurisdiction provision (Article 287), which is: "while signing, ratifying or acceding to this Convention or at any time thereafter, a state shall be free to choose, by means of a written declaration", the International Tribunal for the Law of the Sea, the International Court of Justice, the arbitral tribunal and the special arbitral tribunal to settle the disputes on interpretations or application of this convention, a similar declaration has not been made by China yet. ${ }^{38}$ According to Article 187 of the Convention, the Seabed Disputes Chamber has jurisdiction to hear disputes relating to the interpretations and applications of Part XI of the Convention (the part of "The Area") and disputes relating to seabed area activities between state parties and the International Seabed Authority. All state parties are obliged to accept this jurisdiction. ${ }^{39}$

The што has established a powerful dispute settlement mechanism to regulate international trade. This mechanism is governed by the Rules and Procedures on Dispute Settlement Understanding (hereinafter "Understanding"), an integral part of a package agreement of the wTO.

The systemised and normative provisions of the Understanding far exceed those embodied in the General Agreement on Tariffs and Trade (GATT). A new

36 For example, when China signed and ratified the Convention on the Production, Stockpiling and Use of Chemical Weapons and on Their Destruction, it did not include a reservation to Article 14, a dispute settlement provision to settle disputes by submitting them to the International Court of Justice on the condition that all the disputing parties agree.

37 Tie-ya Wang, International Law, Law Press, 1995, p. 613.

38 In 2006, China made an optional declaration to exclude from the jurisdiction of compulsory procedures all disputes concerning delimitation of the territorial sea, the exclusive economic zone (EEZ) or continental shelf or involving historic bays or titles or relating to some other specified matters such as military activities.

39 Reference to the United Nations Convention on the Law of the Sea, Article 187. Part 15 of this Convention also has an arbitrary compulsory jurisdiction provision (Article 287), which states that while signing, ratifying or acceding to this Convention or at any time thereafter, a state shall be free to choose, by means of a written declaration, the International Tribunal for the Law of the Sea, the International Court of Justice, an arbitral tribunal or a special arbitral tribunal to settle disputes on interpretations or application of this Convention. In 2006, China made an optional declaration to exclude from the jurisdiction of compulsory procedures all disputes concerning delimitation of the territorial sea, the exclusive economic zone (EEZ) or continental shelf or involving historic bays or titles or relating to some other specified matters such as military activities. 
body called the Dispute Settlement Body (DSB), which is an alter ego of the General Council of the WTO, was established to operate the dispute settlement mechanism.

The DSB has compulsory jurisdiction over trade disputes between WTO members. It can establish a panel of experts (Panel) to handle the dispute at the request of a party to the trade dispute. The DSB is able to submit the reports of the Panel, supervise the implementation of the recommendation and approve the compensation measures, if required.

The report of the Panel or the report of the Appellate Body ( $\mathrm{AB}$, a standing body of the WTO) comes into effect automatically unless it is not adopted by the DSв by a consensus, which, in fact, is fairly impractical. The procedure called "negative consensus" is the most prominent feature of the Dispute Settlement Mechanism (DSM) of the wTO.

With its accession to the WTO on 11 December 2001, China has accepted the jurisdiction of the Dispute Settlement Mechanism of the wTO. This represents that China's approach to the settlement of disputes in areas of trade has undergone a significant change.

\section{The Role of International Law and International Institutions in} China's Relations with the Rest of the World

The United Nations Charter forbids states to use military force except in selfdefence or with the approval of the Security Council. ${ }^{40}$ The Security Council has 15 members, of which five are permanent: namely, the United States, Britain, Russia, France and China. These permanent members each hold a power of veto. The Security Council can issue a resolution if nine of the 15 members approve it and none of the permanent members exercises its veto.

The non-defensive use of military force can legally occur, under the formal terms of the UN Charter, only with the consent of these five states. The overall purpose of the UN Charter is to prevent the use of force except in self-defence and to offer in exchange for the voluntary cessation of offensive war a guarantee of collective security.

China used to be one of the few countries that long avoided most international affairs and shunned most international norms. Recognition of the legitimacy of Western-dominated international institutions and norms was alien or unacceptable to China.

$40 \quad$ United Nations Charter, Article 51. 
Recently, as China has risen in power, it has begun to embrace regional and global institutions and to take on responsibilities that come with superpower status. It has embraced much of the current constellation of international institutions, rules and norms.

The stakeholding states need to treat international law flexibly and consistently given the existing balance of power. This suggests that, as China becomes more powerful, other countries, and particularly the United States, may have to renegotiate a host of important multilateral treaties with China.

On China's side, the country was accused of seeking the rights and privileges of a great power without accepting most of the corresponding obligations and responsibilities. ${ }^{41}$ However, based on China's past behaviour, it is an exaggeration to argue that China's actions in the wто have challenged some of the most fundamental norms and rules of the existing international law.

The question now is whether there is a role for international law or institutions in mediating a potential clash between a rising China and the rest of the world. This requires a more complete understanding of the nature of conflict between the status quo powers and China, the rising power.

The possibility of war depends not on the nature of the distribution of power, but on the degree of understanding between states with regard to each other's interests and capacities. An important function of international law and international institutions would be to enhance transparency - the better each state understands another state, the less likely there will be a war between them.

A further question is whether the international judicial system can resolve a possible dispute between China and another country. China has shown its satisfaction with the DSM of the WTO as the international adjudicating body for disputes among states.

As many disputes can be interpreted as trade-related disputes, there is a possibility that these disputes will be understood as disputes concerning trade measures that are subject to WTO agreements. ${ }^{42}$ For other general disputes, China's existing practice shows a strong preference for political settlement.

41 Iain Johston, An Overview of Studies of American Scholars on the Relationship between China and International Organisations (in Chinese), Institute of World Economics and Politics, Chinese Academy of Social Sciences, 2004. and 2, as well as any Plurilateral Trade Agreement in Annex 4 where its committee of signatories has taken a decision to apply the DSU. See Understanding, Article 1 and Appendix 1. According to these articles, the wTo Dispute Settlement Body deals with trade-related disputes including trade in goods, trade in services and trade-related aspects of intellectual property rights. 
When the dispute concerns China's territorial integrity and sovereignty or other vital interests, China's approach is the exclusion of any judicial approach - be it in the form of a judicial body or an arbitral tribunal; China is therefore unlikely to resort to a judicial approach to resolve such disputes.

International judicial institutions such as the ICJ, the International Tribunal for the Law of the Sea and the Permanent Court of Arbitration thus do not have a place in the settlement of territorial disputes between China and its neighbouring countries.

\section{$7 \quad$ Concluding Remarks}

Since 1978, China has actively joined intergovernmental and nongovernmental organisations. The deepening bilateral and multilateral relations between China and Russia, Central Asia, the Association of Southeast Asian Nations, the African countries, the European Union, South Korea and the United States and Japan are examples.

This evolving process represents China's attempt to rebuild its international image, to work within international norms to pursue its interests and to enhance national security. It also shows China's effort to hedge against American influence. More importantly, it signals China's emergence as an active player in the international arena.

Its approach to the settlement of disputes is also illustrative of its attitude towards international law. Both its political approach (including consultation and negotiation, good offices, investigation, etc.) and its juridical approach (such as litigation and international arbitration) are set up as peaceful approaches. In the end, China advocates dispute resolution via dialogue. 